\title{
Changes in the socioeconomic profile of Piauí: From the Spix and Martius expedition
}

\author{
to nowadays \\ Mudanças do perfill socioeconômico do Piauí: Da expedição de Spix e Martius à atualidade \\ Cambios en el perfil socioeconómico de Piauí: De la expedición de Spix y Martius a la actual
}

Received: 04/26/2021 | Reviewed: 05/04/2021 | Accept: 05/09/2021 | Published: 05/23/2021

\author{
Antonia Alikaene de Sá \\ ORCID: https://orcid.org/0000-0003-2479-2324 \\ Universidade Federal do Piauí, Brasil \\ E-mail: allyknsa@hotmail.com \\ Maria Carolina de Abreu \\ ORCID: https://orcid.org/0000-0001-8206-7273 \\ Universidade Federal do Piaú, Brasil \\ E-mail: mariacarolinabreu@hotmail.com \\ Francisco Soares Santos Filho \\ ORCID: https://orcid.org/ 0000-0002-1713-7228 \\ Universidade Estadual do Piauí, Brasil \\ E-mail: fsoaresfilho@gmail.com
}

\begin{abstract}
The study aimed to gather information about the socioeconomic aspects based on the reports from Spix and Martius expedition compared to the present day. The studied region is inserted in the basin of the Canindé River, of the semiarid region of Piauí. The research was based on the report of Spix and Martius's book Viagem pelo Brasil, government websites, province reports and bibliographic research. The main changes that took place in the region were the move of the Capital from Oeiras to Teresina, the use of the navigability of the Parnaíba River and the construction of the Dairy Factory in Campinas, which started wage employment in Piauí. In 1819, the region was sparsely populated (71,370 inhabitants), with low demographic density (- 0.28 inhabitants $\left./ \mathrm{km}^{2}\right)$, there were only the county of Oeiras and some towns. After 200 years, the population reached 3,118,360 with a demographic density of 12.4 inhabitants / $\mathrm{km}^{2}$, which is still considered low. Piauí is currently divided into 224 counties, 16 of which make up the study region, of which Oeiras and Paulistana have the largest population. The entire population today has access to education and the counties with the highest Basic Education Development Index (IDEB) are Oeiras and Acauã. The region is grouped into development territories and its main economic potentials are agribusiness, apiculture, livestock farming, cashew farming, sheep farming and wind power. Even in the face of advances and development, socioeconomic indicators show that the semi-arid region remains underdeveloped, with the need to expand public policies and private sector interventions, identifying the potential of counties, from a regional development perspective.
\end{abstract}

Keywords: Development; Naturalists; Economic potentialities; Semi-arid; Social.

\section{Resumo}

O estudo tratou de levantar informações acerca dos aspectos socioeconômicos com base no relato da expedição de Spix e Martius comparados aos dias atuais. A região estudada fica inserida na bacia do Rio Canindé, da macrorregião semiárida piauiense. A pesquisa baseou-se no relato da obra Viagem pelo Brasil de Spix e Martius, sites governamentais, relatórios da Provincia e levantamento bibliográfico. As principais transformações ocorridas na região foram a mudança da Capital de Oeiras para Teresina, o aproveitamento da navegabilidade do rio Parnaíba e a construção da Fábrica de Laticínios em Campinas, esta última deu início ao trabalho assalariado no Piauí. Em 1819, a região era pouco habitada (71.370 hab.), com baixa densidade demográfica $\left(-0,28 \mathrm{hab} / \mathrm{km}^{2}\right)$, só existia a cidade de Oeiras e algumas vilas. Passados 200 anos, a população alcançou 3.118.360 com densidade demográfica de 12,4 $\mathrm{hab} / \mathrm{km}^{2}$, considerada ainda baixa. Atualmente o Piauí está dividido em 224 municípios, 16 deles perfazem a região de estudo, dos quais, Oeiras e Paulistana apresentam maior contingente populacional. Toda população hoje tem acesso à educação e os municípios com maior IDEB são Oeiras e Acauã. A região está agrupada em territórios de desenvolvimento e suas principais potencialidades econômicas são agronegócio, apicultura, bovinocultura, cajucultura, ovinocaprinocultura e energia eólica. Mesmo diante dos avanços e desenvolvimento, os indicadores socioeconômicos demonstram que a região semiárida continua subdesenvolvida havendo necessidade de ampliação de políticas públicas e intervenções do setor privado, identificando potencialidades dos municípios, sob uma perspectiva de desenvolvimento regional.

Palavras-chave: Desenvolvimento; Naturalistas; Potencialidades econômicas; Semiárido; Social. 


\begin{abstract}
Resumen
El estudio seek compile información about them socio-economic aspects from del report it expedición Spix Martius y en comparación con la actualidad. The studied region is inserted in the river basin of the Canindé River, in the semiarid region of Piaú. La investigación if Baso en el account del libro Travel by Brazil Spix y Martius, sites web gubernamentales, reports of la Provincia y un estudio literature. Los principales cambios that produjeron en la región fueron el shuttle it Oeiras capital Teresina, el aprovechamiento de la navigability del río Parnaíba y la construcción de la Dairy Factory en Campinas, the latter beginning el trabajo asalariado en Piaui. In 1819, the region was sparsely populated (71,370 inhabitants), with low population density (- 0.28 inhabitants $\left./ \mathrm{km}^{2}\right)$, only the city of Oeiras and some localities existed. Después de 200 años, la población alcanzó them 3,118,360 con una densidad population of 12.4 inhabitants / $\mathrm{km}^{2}$, which todavía is considered baja. Currently, Piauí is divided en 224 municipalities, 16 of them cuales conforman la región de estudio of them cuales Oeiras y Paulistana tienen la mayor población. Hoy all la población tiene acceso a la educación y los municipalities con mayor IDEB son Oeiras y Acauã. La región is grouped en territories of desarrollo sus y principales potenciales economic son la agribusiness, it beekeeping, her cattle ranch , el anacardo , el sheep y la energía wind. Included front of them advances y Desarrollos, these socio-economic indicators muestran that la región semiarid remains subdesarrollada, con la necesidad to expand these policies y las Intervenciones del private sector, identifying el potential of these municipalities, since una perspective desarrollo regional.
\end{abstract}

Palabras clave: Desarrollo; Naturalists; Economic potential; Semi arid; Social.

\title{
1. Introduction
}

The arrival of the royal family in Brazil at the beginning of the 19th century led to the opening of ports to foreigners, which also marked the arrival of several naturalists to the country (Lisbon, 1997). In 1817, naturalists Johann Baptist von Spix (zoologist) and Karl Friedrich Philipp von Martius (physician and botanist) arrived in Rio de Janeiro, to start a three-year expedition (1817-1820) in Brazil to study a land, until then, mostly unexplored (Diniz, 2019). These naturalists came to the country in an entourage that accompanied the Archduchess Maria Leopoldine of Austria, who would marry by proxy with D. Pedro de Alcântara, later emperor D. Pedro I of Brazil. The delegation came with specialists of many areas of Natural Sciences (Ramirez, 1968).

With the scientific mission of dedicating themselves to the study of the country's natural history, Spix and Martius, in addition to studying fauna and flora, understood that studying man would also be important to understand nature in all its dimensions (Lopes, 2019). Martius had a Eurocentric vision, where he relegated the position of inferiority to the Indians and Africans in relation to the Europeans. However, years later, the naturalist leaves in his book the novel by Frei Apollonio, who after arriving in Brazil and living with his people and the place, this perception is partially deconstructed (Cruz, 2017).

Spix and Martius got into Piauí through the Serra de Dois Irmãos, currently Acauã, traveled about 500 km through the Piauí state in the southeast (Pernambuco) northwest (Maranhão), between April and May 1819, passing through several farms located in the valley of the rivers Canindé and Piauí until reaching the Parnaíba River, where they went to Maranhão. Martius left a great legacy in his writings on flora in his work Flora Brasiliensis and important descriptions of fauna, mineralogical aspects in addition to information about the socioeconomic aspects of the population in the book Viagem pelo Brasil (Spix \& Martius, 1981).

According to Martius' descriptions, the socioeconomics situation of Piauí at that time was marked by extensive livestock production (Spix \& Martius, 1981), which largely determined the demographic distribution, the availability of labor, the land structure. Consequently, these factors precluded the development of especially agriculture by the concentration of land ownership and allocation of these pasture, besides the absence of stimulating the internal market. Therefore, as techniques of agricultural production almost didn't exist, stabilized Piaui historically as dependent on other regions for the supply of agricultural products (CEPRO, 2013).

The form of settlement and occupation of Piauí took place from the countryside to the coast (Mott, 1985), and a characteristic that marked the process of colonization of the territory since the occupation of its lands was the slow 
transformation of the economic and social structure. From this colonial structure, traits that marked all socioeconomic evolution over the years emerged and consolidated (Alves, 2003). As in other areas of the northern region, the economy of the province of Piauí was defined by the mastery of some basic activities subsistence, imposed by their own historical and environmental conditions, carried out at a little evolved technical level and consequently with low productivity rates (Queiroz, 2006).

From this perspective, considering that in 2019 was the $200^{\text {th }}$ anniversary of the Spix and Martius expedition through Piauí, and considering the importance of the legacy left by these researchers, especially on the report of the socioeconomic scenario, this study brings problematic the following questions: How has the countryside of Piauí changed in the last 200 years? What factors most contributed to the changes? Regarding these questions, the aim was to gather information about the socioeconomic aspects based on the reports from the Spix and Martius expedition compared to today.

\section{Methodology}

\subsection{Study area}

The selection of counties to carry out this research was done by observing the current political-geographical division of Piauí, respecting the route described by Spix \& Martius (1981) and comparing it with Silva (2017) and Lima (2005). Therefore, the current route of the Spix and Martius Expedition in Piauí was delimited, corresponding to the counties of Acauã, Paulistana, Queimada Nova, Jacobina do Piauí, Conceição do Canindé, Simplício Mendes, Campinas do Piauí, Santo Inácio do Piauí, Colônia do Piauí, Oeiras, Santa Rosa do Piauí, Cajazeiras do Piauí, Arraial, Francisco Ayres, Regeneração and Amarante. The counties are located in the Canindé River basin, in the semi-arid macro-region, presenting adverse climatic conditions with most of the dry weather.

\subsection{Research Progress}

The research used was of the bibliographic type, with reading, analysis and gathering of information and discussion (Köche, 2011 \& Pereira et al., 2018). In order to gather information about the Spix and Martius Expedition in Piauí, he traced it through the historical and environmental context, mainly subsidized in the accounts of the book Viagem pelo Brasil (1817 1820) Volumes 1, 2 and 3 (Spix \& Martius, 1981). The analysis of the current social and economic aspects of the study areas was carried out based on data from the Brazilian Institute of Geography and Statistics (IBGE), accessing the IBGE Portal of Cities through the website https://cidades.ibge.gov.br/. For each municipality, the Human Development Indexes (HDI-M), Basic Education Development Index (IDEB), Gross Domestic Product (GDP), demography and the economic potential of each region were analyzed.

\section{Results and Discussion}

\subsection{Change of the Capital of the Province}

Within the context of the socioeconomic scenario, one of the main changes that took place in the semi-arid region visited by Spix and Martius was the change of the Capital (19th century). During the colonial period, specifically in 1761, Oeiras was designated the category of capital of Piauí, meeting the administrative needs of the province (Gandara, 2011). The city was linked to the commercial flow between the states of Maranhão and Bahia, linking the cycle of colonial livestock in the Northeast, which was historically the main economic activity demanded by federal policies of preservation and cultural relevance (Pereira, 2017) 
However, since the colony, there was an unsatisfactory current in relation to the location of the capital, mainly related to the difficulties of transport and communication. The regional historiographical interpretations, official documents, reports by the presidents of the Province were unanimous in pointing out justifications for transferring Oeiras to a location close to a navigation axis of the Parnaíba River, which would improve the captaincy's finances (Gandara, 2011).

Therefore, in 1798, the governor of the Captaincy of São José do Piauí, João de Amorim Pereira, communicated by letter to the Overseas Council, about the move from the capital of Oeiras to the village of São João da Parnaíba (Parnaíba). For the governor, the location would be favorable due to the location of the village being close to the Parnaíba river, which facilitated the navigation of livestock products, as well as foreign trade being inserted in all the navigable basins of the Empire (Vilhena, 2016).

These understandings acted as arguments, in which they questioned the impasses of a province marked by considerable distances, added to the difficulties of transportation for the flow of wealth and the location of the capital located in the hinterland, far from the great rivers. There were also understandings that Oeiras was unable to play an active role as a state development hub. In addition, its physical "isolation" raised doubts even regarding its administrative effectiveness (Gandara, 2011), however, it is worth mentioning that in the colonial period the organization of urban centers in Piauí took place in a planned way:

"Never in colonial history has there been a premeditated effort to create villages as in the case of the assembly of the Captaincy, starting in 1759. In the space of two years, six villages were created in place of existing parishes, in addition to the elevation of the village of Mocha to the category of city and capital, with the name of Oeiras (Vilhena, 2016, p. 111)".

Considering the discussions about the location of the capital of Oeiras, it is worth highlighting the meaning of the term "sertão" which has different concepts. For Amado (1995), sertão is used according to the social and spatial position, being used more in the symbolic than in the geographical context. In Piauí it was used to characterize environmental factors such as the climate that determined the population's way of life and to refer to an isolated and abandoned place by public authorities (Proviência do Piauí, 1861). Thus, it is understood that it was within this context that Oeiras was inserted in the "sertão".

The President, Dr. José Ildefonso de Sousa Ramos, in a report presented to the Provincial Assembly (Proviência do Piauí, 1844), argued that the capital should be installed in a location with water availability and that it would offer advantages in communications with the whole of the province, mainly with the region of greater commercial concentration and the neighboring provinces, which Oeiras did not have, at least in part. However, if the capital was established in Vila de Parnaíba (Parnaíba), it would be on one end of the Province which would not favor the fastest means of communication and the measure would not be the most appropriate (Freitas, 1988).

Following discussions on the transfer of the capital, in 1844 the name of Vila do Poti (Teresina) came up, designated by the law of August 3 of the same year and repealed by the law of August 5, 1850. At that time the president of Piauí, José Antônio Saraiva, went to the place to check its conditions, which he did not like when he visited (Queiroz, 1998). Therefore, Saraiva signaled to the people the advantages offered them by the change of the municipal headquarters when it became a metropolis of Piauí, which was possible, with their support (Nunes, 2007). Through his speech with the locals, he convinced them to build in the most suitable and important place that would be on the banks of the Parnaíba River (Queiroz, 1998).

After all the repercussions for the transfer of the capital had passed, then an assembly was installed and, on July 21, 1985, when Resolution $\mathrm{n}^{\circ} .315$, authorizing the transfer of the capital to Nova Vila do Poti, immediately elevated to the category of city, with the name of Teresina, with capital forums. Considering the importance of transferring the capital mainly 
for the exploration of the Parnaíba River, President Saraiva soon went to transport the collection of the old village and installed the City Hall and other offices in the new headquarters (Gandara, 2011).

Subsequently, by letter dated October 21, 1852, it has completed the transfer of the capital of Piauí: "I am here by to communicate Your Excellency that this Province is at peace, and that it is completely transferred to this city of Teresina, the capital of the Province and that all public offices are functioning regularly." (Queiroz, 1998, p. 27). In the valley of the Parnaíba River, the city of Teresina, destined to be the seat of the political and administrative power of Piauí, would play the role that until then belonged to the city of Oeiras (Gandara, 2011).

The creation of Teresina and the use of the navigability of the Parnaíba river meant a vigor for the province's economy, especially due to the relative development of commercial activities, which contributed to stabilize the city of Parnaíba as the most relevant commercial center in Piauí (Alves, 2003).

However, it is worth noting that, in the last decades of the 19th century, the Piauí market had been going through a sharp crisis, making it more critical since the emergence of the drought between the years 1877 and 1879 . The drought showed the material backwardness of the province and consolidated the perception that the commercial development driven by the transfer of the capital and the use of the navigability of Parnaíba were not enough to provide a generation of wealth that would guarantee the insertion of the province in the development model that the modern paradigm imposed at that time (Vilhena, 2006).

Moreover, the transfer of the capital in 1852 brought about socio-spatial changes, with the appearance of towns and counties along the Parnaíba River, which represented a greater possibility of development for northern towns. These changes were articulated the objectives of the projects of the imperial government, which had bases linked to policy measures for the country, center of the figure of Dom Pedro II (Santana, 1965).

\subsection{Agroindustry by Antônio Sampaio}

In the second half of the 19th century, the economy of Piauí had livestock as its most important economic activity. Although, for the State, it was relatively important for the population, as well as for the generation of income, subsistence agriculture, which was basically limited to local consumption, employed the majority of the population, whose conditions were not sufficient for them to establish themselves. like farmers or traders. Depending on the price situation, cotton, tobacco and, eventually, rice were produced for export (Queiroz, 2006).

Thus, livestock farms were the basis of economic production and a means of civility in the Piauí state backcountry (Cabral, 2020), associated with the rudimentary food crops, calling it a typically subsistence economy. The industrial activity, on the other hand, was only tanning of hides and the handmade production of coarse cotton fabrics (Veloso Filho \& Reydon, 2002). At the beginning of the 19th century, agriculture became an activity of mercantile production, supplying the internal market of Piauí and exporting outside the State. It should be noted that regardless of the region's economic growth, activities needed slave labor (Caetano, 2020).

These economic activities gave rise to the creation of many work categories for rural society (Cabral, 2020), having as elements that formed the state economy in the 18th and 19th centuries the most outstanding were the different types of workers who presented themselves as aggregates or residents, enslaved, squatters, tenants, breeders, cowboys, large landowners and land grants, according Mott (1985), Brandão (1999) and Lima (2005).

Considering that in the Piauí region there were only these two economic bases (livestock and farming), Piauí engineer Antonio José de Sampaio, oriented to the most modern in Europe, landed an agro-industrial project for the countryside of Piauí - the Dairy Factory (Veloso Filho \& Reydon, 2002). Allied with the study experience, in 1889, Antonio Sampaio also 
considered the information of naturalists Spix and Martius and George Gardner, who made important observations about the National Farms, which served as the basis for his development project (Vilhena, 2006). One of the observations made by Martius sums up the project idealized by Antonio Sampaio:

In the places, where the ground opened up, among the closed branches of forest, we were happy both for the close equality of the lush carpet of grass and for the delicacy of the tender glabrous stems, as we had never found the same, the local people call them mimosos fields and used them for pastures of their numerous cattle. We were in the livestock district for the first time, which in a way must be considered the Switzerland of Brazil (Spix \& Martius, 1981, v. 2, p. 230)

As it is possible to observe above, and confirming with the vision of Vilhena (2006), the excerpt of Martius' work seems to explain the reality of two worlds that served as a basis for the idealization of Antonio Sampaio: Europe, a developed Continent and Piauí a backward agrarian state, motivating him to develop an agribusiness in the Swiss models in the hinterland of Piauí, using the most modern technology of the time, both in terms of equipment and machinery and agricultural techniques. In this context, the green fields of the Canindé river valley represented the best source of natural pasture for national farms, in addition, they have a source of Aningas' headwater, a region where the best herd of cattle on the farms was located, leased by Antonio Sampaio (Vilhena, 2006).

The construction of the agribusiness was the first dairy factory in the Northeast. Inaugurated on April 9, 1897, in Campos, on the Castelo farm (currently Campinas do Piauí), resulting from lease agreements whose main object was the National Farms, where the Factory operated until 1947 (Costa, 2010).

Considering the economic and political aspects, the industry sought the development of the National Farms in Piauí, which at the time was the basis of dispute among the local political groups, since the lands were targeted among the State's agrarian elite. From the social point of view, the factory started wage labor in Piauí, a time when slave labor still prevailed (Fé \& Nascimento, 2019).

Antonio Sampaio lost his rights as a tenant of the national Piauí farms are to receive compensation for the existing benefits in the region. The debt contracted by the loan, or loans, would probably be the main reason that led to the bankruptcy of the agribusiness. However, despite his premature death, the achievements seemed to enhance the years of his existence. At a time when the development of Brazil was conditioned to the insertion of European workers, Antonio Sampaio remained at the margin of the speech of regrets in relation to the government's neglect, acting on his own and making the only attempt to introduce labor. immigrant work in Piauí (Vilhena, 2006: Fé \& Nascimento, 2019).

Furthermore, after more than one hundred years of his death, there is, to this day, no other record in the history of Piauí of isolated private initiative in the field of agroindustry that matches the experience of Antonio Sampaio (Fé \& Nascimento, 2019). The Factory is an architectural document that tells a valuable fragment of the history of the formation of Piauí and Brazil (Costa, 2010), (Figure 1). 
Figure 1 - A - External view. B and C - Internal view of the Dairy Factory in the County of Campinas do Piauí.

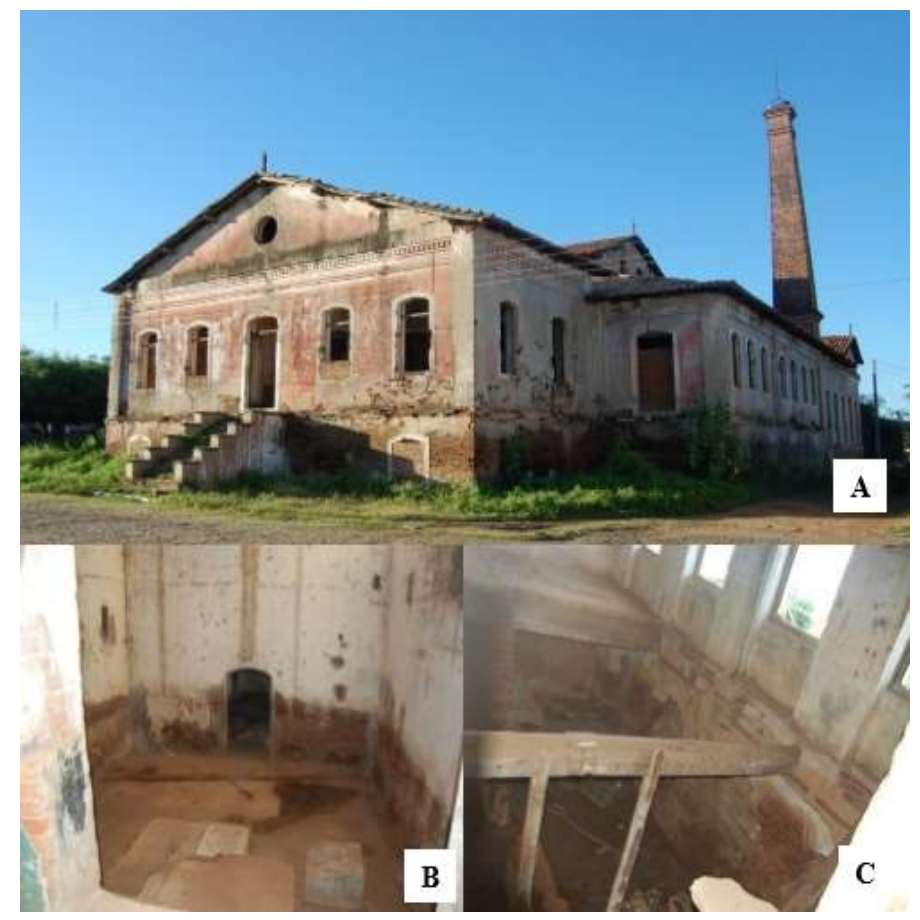

Source: Sá, Antonia Alikaene (2019).

Doe to the abandonment of the Dairy Factory building, it was listed by the National Historical and Artistic Heritage Institute (IPHAN), as a National Historic Monument (Brazil, 2014).

Therefore, the realization and execution of a project to revitalize the old Dairy Factory in the Piauí backlands would be a representation to preserve the memory of a society that holds the historical and architectural value of the factory, which was the biggest contributor to socioeconomic and in the state of Piauí, promoting a relationship between rural and industrial architecture from the colonial era.

\subsection{Comparative historical parallel of socioeconomic aspects}

Since the colonization of Brazil, it has always been Portugal's interest to make its domains known, the economic possibilities, the farms and the population of the province. The collection of this information was carried out through the population census, considering that the first Brazilian Demographic Census dated 1870. In this sense, the Church, at the recommendation of the State, through ecclesiastical authorities, according to the circumstances and orders received, wrote down the "fires and the relation of its residents", that is, during their jurisdictions they made a census of the population and properties of Piauí. It is worth mentioning that the first population census carried out in Piauí territory, data from 1694 and 1697, was by Father Miguel de Carvalho (Silva, 2017).

When Spix and Martius passed through Piauí, the population was 71,370 inhabitants, including all ethnicities, with a very low demographic density of only 0.28 inhabitants/ $\mathrm{km}^{2}$, of which 14,074 lived in the extensive parish of Oeiras, which was the main commercial cycle area, according to the list of official data provided by Governor Baltasar de Sousa Botelho and Vasconcelos (Spix \& Martius, 1981). After 200 years, the population of Piauí reached, in the last census of 2010, a total of 3,118,360 inhabitants, which is considered, given the size of the population and the geographical extension, a low demographic density, of only $12.4 \mathrm{hab} / \mathrm{km}^{2}$. Of the total inhabitants, 814,230 live in Teresina (IBGE, 2010). It is evident that despite the 
changes occurred in the last two centuries, with the increase of the population and demographic density, the populations living in the capitals of today and yesterday remain in close quantities (above $20 \%$ of the total population of the state).

In 1819, in Piauí there was no division of counties, the territory was organized into a host city (Oeiras) and six villages: Vila de Parnaíba (Parnaíba), Parnaguá, Jerumenha, Valença, Campo Maior and Marvão (Castelo do Piauí) (Arraes, 2016). Currently, the state is divided into 224 counties (IBGE, 2010), of which, according to the route described by Spix \& Martius (1981) and compared with Lima (2005) and Silva (2017), 16 counties comprise the region of the expedition of Spix and Martius after 200 years of their passage through the interior of the State, and, according to data from the IBGE (2010; 2020), the cities that concentrate the largest population in this region are Oeiras, Paulistana and Amarante (Table 1). Therefore, it is observed that Oeiras and Amarante for being the main economic centers remain among the most populous to the present day.

Table 1 - Estimated population by county for 2020, population by county and demographic density in the last census (2010), of the Spix and Martius expedition region 200 years after the expedition in Piauí.

\begin{tabular}{lccc}
\hline \multicolumn{1}{c}{ Counties } & $\begin{array}{c}\text { Estimated } \\
\text { population (2020) }\end{array}$ & $\begin{array}{c}\text { Census population } \\
\mathbf{( 2 0 1 0 )}\end{array}$ & $\begin{array}{c}\text { Demographic density } \\
\mathbf{( 2 0 1 0 )}\end{array}$ \\
\hline Acauã & 7,102 & 6.749 & 5.27 \\
\hline Amarante & 17,604 & 17.135 & 14.83 \\
\hline Arraial & 4,720 & 4.688 & 6.87 \\
\hline Cajazeiras & 3,573 & 3.343 & 6.5 \\
\hline Campinas do Piauí & 5,620 & 5.408 & 6.51 \\
\hline Colônia do Piauí & 7,661 & 7.433 & 7.84 \\
\hline Conceição de Canindé & 4,807 & 4.475 & 5.38 \\
\hline Francisco Ayres & 4,323 & 4.477 & 6.82 \\
\hline Jacobina do Piauí & 5,729 & 5.722 & 4.17 \\
\hline Oeiras & 37,085 & 35.640 & 13.19 \\
\hline Paulistana & 20,554 & 19,785 & 10.04 \\
\hline Queimada nova & 9,017 & 8,553 & 6.32 \\
\hline Regeneração & 17,979 & 17,556 & 14.03 \\
\hline Santa Rosa do Piauí & 5,255 & 5,149 & 15.14 \\
\hline Santo Inácio do Piauí & 3,803 & 3,648 & 4.28 \\
\hline Simplício Mendes & 12,746 & 12,077 & 8.97 \\
\hline & Total: 162,323 & & \\
\hline
\end{tabular}

Source: IBGE (2010; 2020), Authors (2021).

Health as well as education are the foundation of socio-economic growth in a region. Therefore, based on the descriptions of Spix and Martius (Spix \& Martius, 1981), the population's health was precarious at the time, where there were only two surgeons and no clinicians, a pharmacy in inadequate operating conditions with medicines brought from Bahia and / or Maranhão and good part of the population affected by several diseases, such as gastric diseases, flatulence, dyspepsia, diabetes, cardiodynia, sore throat, inflammation of the eyes with cataracts, cornea opacity, in addition to nervous diseases. However, in view of this condition, there was only one hospital installed in the city of Oeiras with 40 beds for soldiers (Spix \& Martius, 1981). 
The number of hospitals together with the number of hospital beds are important indicators of the resources available for the population's health (Brasil, 2019). Thus, through information from IBGE (2009), it was found that currently in the region there are 128 health establishments and 337 public hospital beds, distributed to a total of 161,838 people. Based on these figures, it appears that in terms of hospital beds they are equivalent to 2 beds for every 1,000 inhabitants. Although the World Health Organization (WHO) does not have an official recommendation, an average of 3.2hospital beds per 1,000 inhabitants is estimated globally (WHO, 2017).

Therefore, considering today's figures from yesterday, it appears that when compared to the size of the population, the resources available in public health in that region, although it has improved in seeking to provide assistance to prolong people's quality of life, it still does not have an adequate coverage to meet the population's demand. Regard to the health panorama of the population in the region, the disease with the highest number of hospitalizations in the last survey pointed out by the IBGE (2016), was diarrhea with a rate of 3.7 per thousand inhabitants.

Regarding access to education, in the region there was only one Jesuit school known as the Casa do Vigário in Oeiras (Spix \& Martius, 1981). With the states socioeconomic development, the entire population today has access to education, with high rates of students in public school education, as well as an establishment to meet the demand of each county. The areas with the highest development rates for Basic Education (IDEB) are Oeiras with 5.7 and Acauã with 5.6 for the initial years $\left(1^{\text {st }}\right.$ to $5^{\text {th }}$ year), already for the final years ( $6^{\text {th }}$ to $9^{\text {th }}$ year), Jacobina presented mean of 4.6 and Oeiras 4.3 (INEP, 2019), (Table 2). In addition to basic education, the region has the education centers of the Universidade Federal (UFPI), Universidade Estadual do Piauí (UESPI) and the Instituto Federal do Piauí (IFPI), as well as other private institutions of higher education. Thus, it appears that in terms of education the region has evolved positively.

Table 2 - Schooling rate from 6 to 14 years of age, Basic Education Development Index - IDEB of Elementary Education - EE from public schools, numbers of schools with Elementary Education and High School - HS and * undisclosed results from the countries that constitute the route of the Spix and Martius excursion in Piauí.

\begin{tabular}{|c|c|c|c|c|c|}
\hline Counties & $\begin{array}{l}\text { Schooling } \\
\text { (2010) }\end{array}$ & $\begin{array}{c}\text { IDEB - Early } \\
\text { years (2019) }\end{array}$ & $\begin{array}{c}\text { IDEB - } \\
\text { Final years } \\
(2019)\end{array}$ & $\begin{array}{c}\mathrm{N}^{\circ} \text { of EE } \\
\text { Establishments } \\
(\mathbf{2 0 1 8})\end{array}$ & $\begin{array}{c}\mathbf{N}^{\circ} \text { of } \mathrm{HS} \\
\text { Schools } \\
(2018)\end{array}$ \\
\hline Acauã & $97.5 \%$ & 5.6 & 3.9 & 6 & 1 \\
\hline Amarante & $97.2 \%$ & 3.8 & 2.7 & 26 & 3 \\
\hline Arraial & $97.7 \%$ & 4.3 & 3.9 & 9 & 1 \\
\hline Cajazeiras & $99.2 \%$ & 3.9 & 2.5 & 12 & 2 \\
\hline Campinas do Piauí & $97.8 \%$ & 3.5 & 3.8 & 15 & 1 \\
\hline Colônia do Piauí & $98.6 \%$ & 4.8 & 3.0 & 8 & 1 \\
\hline Conceição de Canindé & $96.8 \%$ & 3.8 & 3.8 & 6 & 1 \\
\hline Francisco Ayres & $98.1 \%$ & 4.1 & 3.9 & 9 & 1 \\
\hline Jacobina do Piauí & $97.7 \%$ & 3.8 & 4.6 & 14 & 1 \\
\hline Oeiras & $97.9 \%$ & 5.7 & 4.3 & 36 & 11 \\
\hline Paulistana & $97.9 \%$ & 4.5 & 3.6 & 20 & 4 \\
\hline Queimada nova & $99.3 \%$ & 3.8 & $*$ & 4 & 1 \\
\hline Regeneração & $97.4 \%$ & 3.6 & 3.2 & 14 & 3 \\
\hline Santa Rosa do Piauí & $99.0 \%$ & 5.0 & 3.7 & 4 & 1 \\
\hline Santo Inácio do Piauí & $99.3 \%$ & 4.9 & 3.6 & 2 & 2 \\
\hline Simplício Mendes & $98.6 \%$ & 4.8 & 3.6 & 11 & 4 \\
\hline
\end{tabular}

Source: IBGE (2010; 2018); INEP (2019), Authors (2021). 
The economy is measured by the Gross Domestic Product (GDP), an indicator of the sum of all goods and services produced in a given region (City, State or Country) in a given period. Thus, the higher the GDP in a period, the higher the level of production of an economy, and, as stated by Cimoli et al. (2017), its ability to generate wealth. Regard to the region under study, according to IBGE data, it was observed that the counties with the greatest economic dynamics are Oeiras and Simplício Mendes, places where there are more commercial establishments with a greater number of employed people (Figure 3).

It should also be noted that in 2017 the IBGE verified different patterns of interaction in the Piauí territory when considering the main sector of economic activity in the county, that is, the gross added value of the sector that contributed most to GDP. In turn, services (except public administration) were highly relevant in 16 counties of Piauí, including Oeiras and Simplício Mendes, as shown in Figure 3.

Figure 3 - GDP per capita by county in the Spix and Martius expedition region in Piauí.

\section{GDP per capita}

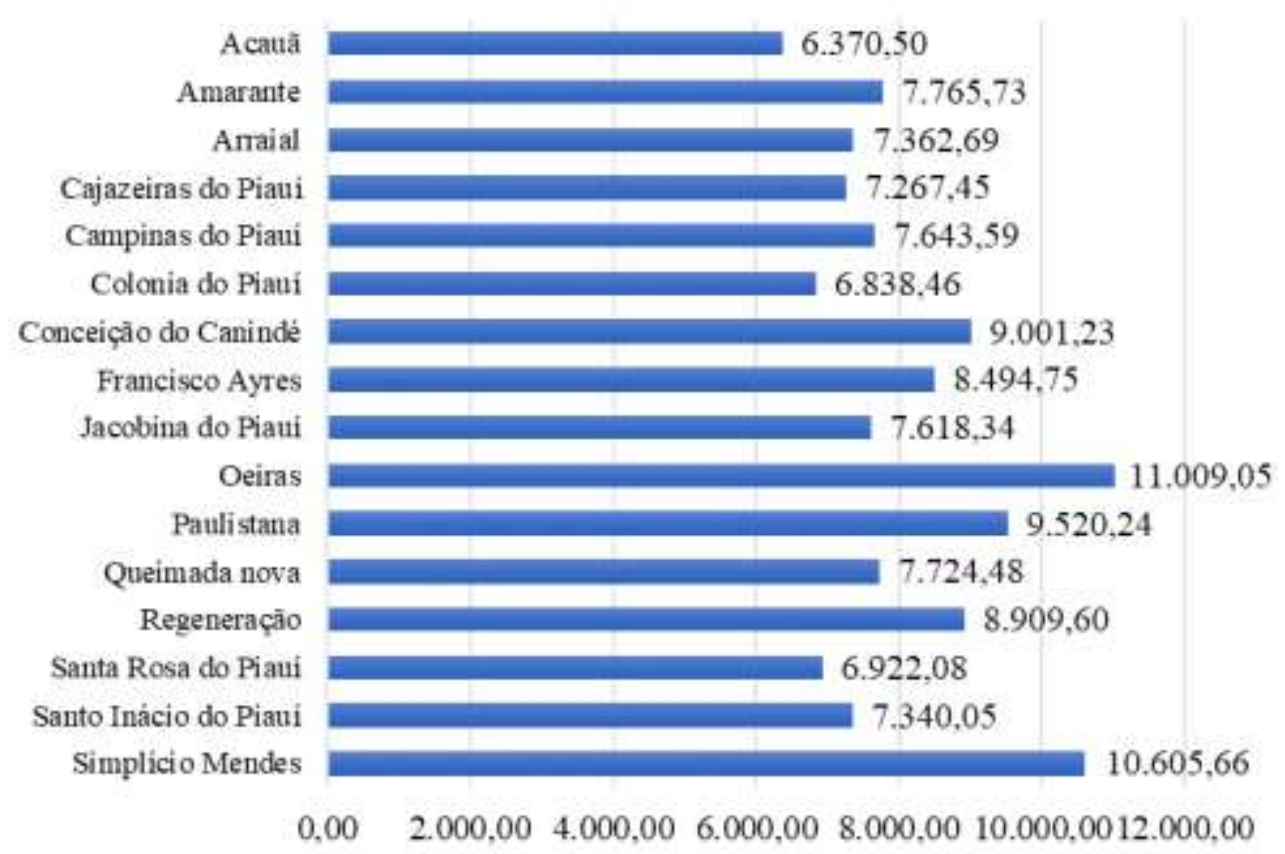

Source: IBGE (2017), Authors (2021).

As for the HDI (Human Development Index), an index that integrates education, health and income indicators, in Piaui it was 0.646 in 2010, slightly below the Northeast in the same year (0.660) and Brazil (0.726). The index increase in the recent years, presupposes improvements in the state's social framework, since the HDI is in line with the reduction of income inequality in the population, where the improvements can be attributed to government income transfer and training programs. for the labor market in addition to the increase in the minimum wage (IBGE, 2010). The Figure 4 shows the HDI of the counties that make up the path of Spix Expedition and Martius 200 years after in the countryside of Piaui, where you can see that the cities with the highest IDHM the region are Oeiras (still the most developed), followed by Simplicio Mendes and Santo Inácio do Piauí. 
Figure 4 - Municipal Human Development Index (MHDI) in the places where the Spix and Martius expedition in Piauí went, 200 years later.

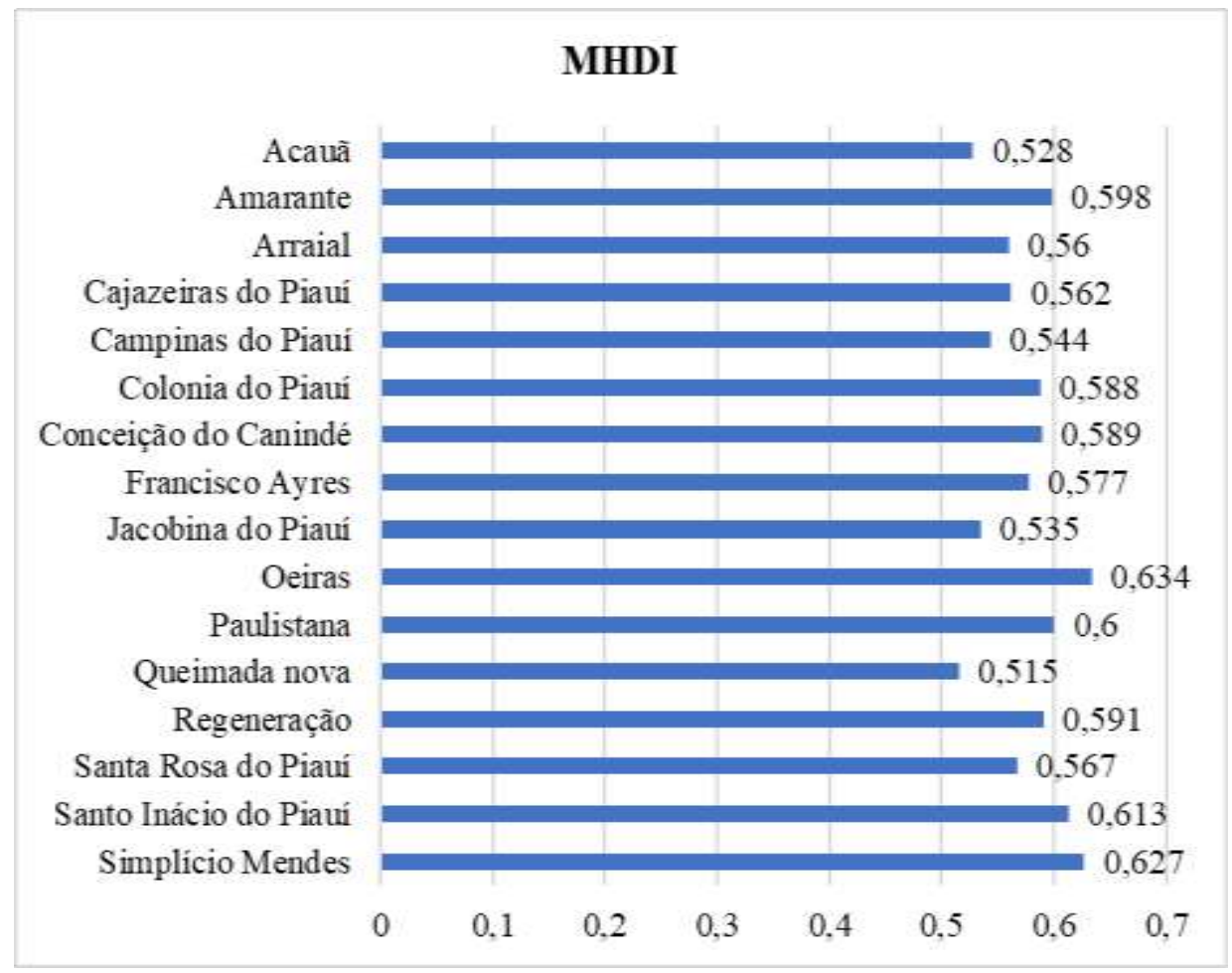

Source: IBGE (2010), Authors (2021).

\subsection{Development Territories}

In 19th century Piauí, the main economic activities developed were extensive livestock and the production of agricultural products (Cabral, 2020). Agriculture was limited to planting crops for subsistence, since most of the land was used for livestock farming. In this context, a society developed, whose way of life was associated with livestock dynamics (Spix \& Martius, 1981).

Currently, the State of Piauí has public policies with the division called "Development Territories" instituted by law (Complementary Law No. 87, of August 22, 2007) that "establishes the Participatory Territorial Planning for the Sustainable Development of the State, bringing together the counties according to their own characteristics and economic potential. There are twelve "Development Territories" (Piauí, 2007), among which four are inserted in the path of the Spix and Martius expedition. The potentialities of these territories are mainly, agribusiness, apiculture, cashew farming, livestock farming, sheep farming and wind power. The forms of economic potential are related, above all, as the vegetation domains of these regions being appropriate for the cultures. The predominant vegetation in the region is from Caatinga environments as well as Caating a Cerrado, which constitutes a transition vegetation (Castro, 2007), (Chart 1). 


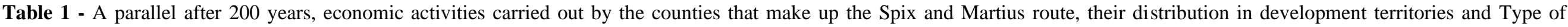
vegetation.

\begin{tabular}{|c|c|c|c|c|c|c|}
\hline $\begin{array}{c}\text { Region where Spix and Martius } \\
\text { passed in } 1819\end{array}$ & \multirow{17}{*}{ 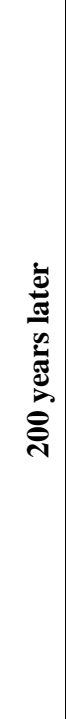 } & $\begin{array}{c}\text { Development } \\
\text { Territories } \\
\end{array}$ & Economic Potentialities & Counties & Area $\left(\mathbf{k m}^{2}\right)$ & Vegetation \\
\hline \multirow{5}{*}{$\begin{array}{l}\text { Main economic activity: Livestock and } \\
\text { subsistence farming. } \\
\text { A city: Oeiras } \\
\text { Avillage: Mocha in Oeiras }\end{array}$} & & \multirow{4}{*}{$\begin{array}{l}\text { Chapada Vale } \\
\text { do Itaim }\end{array}$} & \multirow{4}{*}{$\begin{array}{l}\text { Agribusiness, Apiculture } \\
\text { livestock farming, Wind power, } \\
\text { Mining, Goat farming }\end{array}$} & Acauã & $1,279.59$ & Caatinga \\
\hline & & & & Jacobina & $1,333.79$ & Caatinga \\
\hline & & & & Paulistana & $1,941.39$ & Caatinga \\
\hline & & & & Queimada Nova & $1,284.67$ & Caatinga \\
\hline & & \multirow{8}{*}{ Vale do Canindé } & \multirow{8}{*}{$\begin{array}{l}\text { Apiculture livestock arming, } \\
\text { Goat farming, cashew farming, } \\
\text { Tourism, Mining }\end{array}$} & Conceição do Canindé & 824,729 & Caatinga \\
\hline Farms: Serrinha, Serra Branca, & & & & Simplício Mendes & 852,892 & Caatinga \\
\hline Cachoeira, Santa Isabel, Porções de & & & & Campinas do Piauí & 831,201 & Caatinga \\
\hline $\begin{array}{l}\text { cıma, Bom Jardım, Poçoes de Baıxo, } \\
\text { Campo Grande, Castelo, Brejo, Illha }\end{array}$ & & & & Santo Inácio & $1,353.39$ & Caatinga \\
\hline $\begin{array}{l}\text { Campo Grande, Castelo, Brejo, Ina } \\
\text { From Oeiras: Farms Olho d'água, }\end{array}$ & & & & Colônia do Piauí & 947,879 & Caatinga \\
\hline Inhuma, Gameleira, Mocambo, & & & & Oeiras & $2,702.49$ & Caatinga; Cerrado \\
\hline Localidade Serra de São Gonçalo do & & & & Santa Rosa & 340,198 & Caatinga; Cerrado \\
\hline Amarante, Fazenda Coité, Buriti, São & & & & Cajazeiras & 514,364 & Caatinga; Cerrado \\
\hline Pedro, Todos os Santos and & & \multirow{2}{*}{$\begin{array}{l}\text { Vale dos Rios } \\
\text { Piauí e Itaueira }\end{array}$} & \multirow[b]{2}{*}{-} & Arraial & 682,761 & Caatinga; Cerrado \\
\hline Sobradinho. & & & & Francisco Ayres & 656,475 & Caatinga; Cerrado \\
\hline Environment: Caatinga with the & & \multirow[b]{2}{*}{ Entre Rios } & \multirow{2}{*}{$\begin{array}{l}\text { Agribusiness, Agroindustry, } \\
\text { Hydroelectric power, Tourism }\end{array}$} & Amarante & $1,155.21$ & Caatinga; Cerrado \\
\hline $\begin{array}{l}\text { presence of many buritizais "palm } \\
\text { trees" from Oeiras. }\end{array}$ & & & & Regeneração & $1,251.04$ & Caatinga; Cerrado \\
\hline
\end{tabular}

Source: Spix \& Martius (1981), Castro (2007); Piauí (2007); IBGE (2019), Authors (2021). 
The territory of Vale do Itaim and Vale do Canindé are characterized by their insertion in the Northeastern semi-arid area. The Vale do Canindé linked to Oeiras has a historical configuration because it is considered the oldest city in Piauí and from where the settlement of other counties in Piauí began (Pereira, 2017). In the Territory Vale dos Rios Piauí and Itaueira, for the counties under study, there was no highlight of economic potential, and, finally, the Entre Rios territory, presents a set of dynamic and economically consolidated activities.

Agriculture has been modernizing with the use of machinery and pesticides, which reduce the work in the countryside, probably being a factor that leads the population to move to the cities. The region has several crops that have not been cultivated for two centuries, and they can be permanent or temporary. The main permanent crops are bananas, cashews, coconut and mango, while the main temporary crops are pumpkin, beans, rice, manioc, corn, watermelon and sorghum (IBGE, 2017).

The raising of small animals such as chickens, goats, sheep, pigs and bees stands out in the region because they are activities adapted to the semi-arid climate. These activities are carried out mainly by small producers and are an important income base for the support of families. Likewise, cattle ranching is present in all counties, varying only in terms of concentration and purpose, however, in small quantities when compared to two centuries ago. The increase in bovine production is related to more favorable climatic conditions, in the case of the Caatinga in the rainy season, in addition to the genetic pattern of the herd (Brainer \& Ximenes, 2015).

Over the years, there has been both a demographic growth and the introduction of other sectors to add to the socioeconomic profile of Piauí, with the industry being an important demand for agricultural products, processors and beneficiaries of vegetable products and oils, in addition to the beverage industries. The Industrial Services of Public Utility (ISPU) were constituted by the production and distribution of electricity and gas, water, sewage and urban cleaning. In this context of socioeconomic changes, industry is a key element for sustained economic growth and the development of the state (Brainer \& Ximenes, 2015). Among the studied areas, the county of Oeiras stands out with the industry, commerce, and agribusiness services, mainly with cashew farming and goat farming (IBGE, 2017).

Currently, structural works and investments in the region are being built in order to benefit rail transportation and, in turn, facilitate the transit of people and goods through the state. The construction of the Nova Transnordestina Railway aims to establish connections between the county of Eliseu Martins and the ports of Pecém - CE and Suape - PE. The construction of multimodal terminals for the project includes the counties of Paulistana and Simplício Mendes (Vale do Canindé) (Biachi \& Macedo, 2018). In addition, the semi-arid region has the installation of the wind farm in the town of Queimada Nova (Chapada Vale do Itaim), where the investment brings socioeconomic importance producing energy and creating jobs in several areas, providing thus improving the life quality of population (Piauí, 2019). These changes in the regional context demonstrate the modification of the natural space in a built encouraged both by the power of the public and the private sector.

In addition to the industrial sector, tourism and ecotourism has been presenting itself as a possibility for the region's socioeconomic situation, such as Oeiras and Amarante (Valente Junior \& Lourenço, 2015). Oeiras was the first historical and cultural center of Piauí and due to the expansion of cultural parameters linked to local activities, as well as heritage education actions and, consequently, the living conditions of the neediest population, it is relevant, which makes the county the center of social and economic development for the semiarid region (Pereira, 2017).

However, since the incentive for development aims at balance between the regions, even when appropriate strategies are used for each one of them, it is observed that for the region under study, mainly because it is configured in the Brazilian semiarid region, it requires more institutions and changes structural measures capable of reducing social inequalities. As stated 
by Dathein (2018), the productive structure plays an important role in the development of production, for economic growth, as well as for the generation of income and poverty. Therefore, if there is investment and these are stimulated, economic growth will certainly occur (Cimoli et al., 2017).

\section{Conclusion}

In view of the historical formation process of the Piauí territory, the State still has major socioeconomic limitations, especially in the region where the Spix and Martius expedition went, which is in the semi-arid region where the climatic conditions are marked by drought and lack of rain, consequently affecting the economy.

After 200 years, it is observed that within the context of the socioeconomic scenario, despite the attempts to undertake projects in the region, the transformations took place slowly and with little evolution. The use of land was the main factor for the modification of the economy, limited to livestock and crops, which, although it was slow, technological advances allowed the diversification of work. And these transformations occurred on socioeconomic small capacity change, thus indicating structural changes low capacity compared to other regions of the state, for example in the Cerrado.

The most developed county in the study area is Oeiras. However, in general, the region remains underdeveloped, with low population density, the health conditions available are still incipient, GDP and MHDI are low. Thus, it is evident that only education has advanced levels of Basic and Higher Education and a high level of schooling in basic education.

However, despite the low socioeconomic indicators, the region has varied economic potential, demonstrating the capacity for investment and growth where the results of this research point to the need to expand public policies more focused on the semi-arid region and interventions by the private sector, identifying the potential of each of the counties, from a regional development perspective.

Therefore, this study brings great scientific contributions that will serve as a basis to guide new studies, since it exposes traces of socioeconomic information mainly from IBGE data, which serve to better understand what still needs to be done in the State, and that it can be a new object of study related to the environmental context, being able to generate more unprecedented discussions on the theme and thus promote the dissemination of knowledge.

\section{References}

Alves, V. E. L. (2003). As bases históricas da formação territorial piauiense. Geosul, 18 (36), 55-76.

Amado, J. (1995). Região, Sertão e Nação. Revista Estudos Históricos, 8(15), 145-152.

Arraes, E. (2016). Plantar povoações no território:(re) construindo a urbanização da capitania do Piauí, 1697-1761. Anais do Museu Paulista: História e Cultura Material, 24(1), 257-298.

Biachi, A. P. T., \& Macedo, F. C. (2018). Ferrovia Nova Transnordestina e Organização Espacial. Mercator, 17.

Brainer, M. S. C. P., \& Ximenes, L. J. F. (2015). Pecuária. In: Perfil Socioeconômico do Piauí. 43-55BNB.

Brandão, T. M. P. (1999). O escravo na formação social do Piauí: perspectiva histórica do século XVIII. Editora Universitária da UFPI.

Brasil. (2014). Instituto de Patrimônio Histórico e Artístico Nacional (IPHAN). Brasília.http://portal.iphan.gov.br/uploads/ckfinder/arquivos/Banco_de_Pare cer es_Tombamento_Estabelecimento_das_Fazendas_Nacionais_do_Piaui.pdf.

Brasil (2019). Cenário dos Hospitais no Brasil. Federação Brasileira de Hospitais e Confederação Nacional de Saúde. Brasília, CNSAUDE 107 - p. http://cnsaude.org.br/wpcontent/uploads/2019/05/CenarioDosHospitaisNoBrasil2019CNSaudeFBH.pdf. Acessed: 15. Jun.2020.

Cabral, I. C. (2020). O vínculo com a terra e as diferentes categorias de trabalhadores rurais livres no Piauí oitocentista. Vozes, Pretérito \& Devir: Revista de história da UESPI, 11(1), 147-167.

Caetano, R. (2020). Uma economia em outono: trabalhadores escravos ligados ao labor. Almanack, (24), ea03318.

Castro, A. A. J. F. (2007). Unidades de planejamento: uma proposta para o Estado do Piauí com base na dimensão diversidade de ecossistemas. Publicações avulsas em conservação de ecossistemas, 18, 1-28. 
Research, Society and Development, v. 10, n. 6, e14510615492, 2021

(CC BY 4.0) | ISSN 2525-3409 | DOI: http://dx.doi.org/10.33448/rsd-v10i6.15492

CEPRO. (2013). Plano de Desenvolvimento Econômico Sustentável do Piauí (Piauí 2050). Fundação CEPRO. Teresina, 292 p.

Cimoli, M., Porcile, G., Martins Neto, A., \& Sossdorf, F. (2017). Productivity, social expenditure and income distribution in Latin America. Brazilian Journal of Political Economy, 37(4), 660-679.

COSTA, A. A. A. (2010). O processo de preservação da Fábrica de Lacticínios das Fazendas Nacionais em Campinas do Piauí. Labor e Engenho, 4(4), 78-92.

Cruz, P. C. (2017). Frey Apollonio? Um Romance do Brasil que o leitor brasileiro desconhece. Nova Revista Amazônica, 5 (3), $55-62$.

Dathein, R. (2018). Estrutura econômica, gastos sociais, distribuição de renda e rentabilidade no Brasil entre 2000 e 2015 : uma análise de suas relações e determinações sobre o crescimento econômico. Revista da Sociedade Brasileira de Economia Política. (50), p 1-18.

Diniz, L. F. A. (2019). Narrativas cartográficas-Volume 1.

Fé, C. C. M., \& Nascimento, F. A. (2019). Paredes da memória: a fábrica de laticínios Puro Leite em Campinas do Piauí, em busca da construção da sua memória (1897-1945). ANPHU-Brasil - 30 Simpósio Nacional de História - Recife.

Freitas, C. (1988). História de Teresina. Fundação Cultural Mons. Chaves, 227.

Gandara, G. S. (2011). Teresina: a capital sonhada do Brasil oitocentista. História (São Paulo), 30(1), 90-113.

IBGE. (2009). Instituto Brasileiro de geografia e Estatística. Estabelecimentos de Saúde SUS. Assistência Médica Sanitária.

IBGE (2010). Instituto Brasileiro de geografia e Estatística. Censo demográfico, 2010. Índice de Desenvolvimento Humano (IDH): Programa das Nações Unidas para o Desenvolvimento - PNUD.

IBGE (2010). Instituto Brasileiro de Geografia e Estatística. População no último censo. Censo Demográfico, 2010.

IBGE (2010). Instituto Brasileiro de Geografia e Estatística. Densidade demográfica: IBGE, Censo Demográfico 2010, Área territorial brasileira. Rio de Janeiro: IBGE, 2011.

IBGE (2016). Instituto Brasileiro de Geografia e Estatística. Internações por diarreia: Ministério da Saúde, DATASUS - Departamento de Informática do SUS, IBGE, Estimativas de população residente.

IBGE (2017). Instituto Brasileiro de Geografia e Estatística. PIB per capita: IBGE, em parceria com os Órgãos Estaduais de Estatística, Secretarias Estaduais de Governo e Superintendência da Zona Franca de Manaus - SUFRAMA.

IBGE (2018). Instituto Brasileiro de Geografia e Estatística. Número de estabelecimentos de ensino fundamental e Ensino Médio: Instituto Nacional de Estudos e Pesquisas Educacionais Anísio Teixeira. Sinopse Estatística da Educação Básica. Brasília: Inep, 2019.

IBGE (2018). Instituto Brasileiro de Geografia e Estatística. Matrículas no ensino fundamenta e ensino médio: Instituto Nacional de Estudos e Pesquisas Educacionais Anísio Teixeira. Sinopse Estatística da Educação Básica. Inep, 2019.

IBGE (2018). Instituto Brasileiro de Geografia e Estatística. Resultados do Censo Agropecuário, 2017.

IBGE (2020). Instituto Brasileiro de Geografia e Estatística. População estimada. Diretoria de Pesquisas, Coordenação de População e Indicadores Sociais, Estimativas da população residente com data de referência $1^{\circ}$ de julho de 2020.

INEP (2019). Instituto Nacional de Estudos e Pesquisas Educacionais Anísio Teixeira. Ministério da Educação (2019). Censo Educacional 2019. IDEB Anos iniciais e finais do ensino fundamental (Rede pública).

Lima, S. O. (2005). Braço forte: trabalho escravo nas fazendas da nação no Piauí, 1822-1871 (Vol. 4). Universidade de Passo Fundo.

Lisboa, K. M. (1997). A Nova Atlântida de Spix e Martius: natureza e civilização na Viagem pelo Brasil (1817-1820). (Vol. 29). Editora Hucitec.

LOPES, M. (2019). Carl von Martius, o alemão que explorou as entranhas do Brasil e 'batizou' nossa natureza. BBC News Brasil. São Paulo. https://www.bbc.com/portuguese/brasil-46995817. Acesso em: 08 jun. 2020.

MOTT, L. R. B. (1985). Fazendas de gado do Piauí: 1697-1762. In: Mott, L. R. B. Piauí colonial: população, economia e sociedade. Teresina: Projeto Petrônio Portela, 45 p.

NUNES, O. (2007). Pesquisa para a história do Piauí: Lutas partidárias e a situação da província. Teresina: Fundapi, 4.

Organização Mundial da Saúde (OMS). (2017). 2.12. World Development Indicators: Health Systems. Genebra: OMS. http://wdi.worldbank.org/table/2.12\#.

Pereira, A. S., Shitsuka, D. M., Parreira, F. J., \& Shitsuka, R. (2018). Metodologia da pesquisa científica. UFSM.

Pereira, D. C. (2017). A cidade-patrimônio de Oeiras-PI e as políticas públicas de preservação do patrimônio cultural no século XXI. Revista Memória em Rede, 9 (16), 142-164.

PIAUÍ (2007). Leis, decretos, etc. Lei complementar n 87 de 22 de agosto de 2007. Legislação do Estado do Piauí.

PIAUÍ (2019). Governo do Estado. Energias Renováveis. https://www.pi.gov.br/notícias/piaui-tem-maior-parque-eolico-em-construcao-na-america-do-sul/.

Província do Piauí. Relatório com que o Exm. Sr. presidente da província do Piauí Dr. Manoel Antônio Duarte de Azevedo passou administração ao Exm. Vice-presidente Dr. José Marianno Lustoza do Amaral no dia 15 de abril de 1861. 
Research, Society and Development, v. 10, n. 6, e14510615492, 2021

(CC BY 4.0) | ISSN 2525-3409 | DOI: http://dx.doi.org/10.33448/rsd-v10i6.15492

Província do Piauí. Relatório do Presidente Dr. José Ildefonso de Sousa Ramos dirigido à Assembleia Legislativa Provincial do Piauí em 7 de julho de 1844.

Queiroz, T. (2006). Economia piauiense da pecuária ao extrativismo. Editora Gráfica da UFPI.

Queiroz, T. D. J. M. (1998). História, Literatura, Sociabilidades. Fundação Cultural Monsenhor Chaves, 639 p., 1998.

Ramirez, E. S. (1968). As relações entre a Áustria e o Brasil, 1815-1889. Brasiliana.

Santana, R. N. M. D. (1965). Perspectiva Histórica do Piauí. Cultura.

Silva, R. M. (2017). Documentos. Revista do Instituto Histórico e Geográfico do Piauí. Ano 99, n. 7 (2017-2018). Teresina. 202 p.

Spix, J. B. V., \& Martius, C. V. (1981). Viagem pelo Brasil: 1817-1820. : Itatiaia, 2.

Valente Junior, A. S., \& Lourenço, I. A. (2015). Turismo. In: Perfil Socioeconômico do Piauí. p. 101-107. BNB. 2015.

Veloso Filho, F. D. A. (2002). Visão geral da economia piauiense na segunda metade do século XX. Publ. Avulsas ciênc. Ambiente, 7, 1-29.

Vilhena, G. H. R. D. (2016). Os fazedores de cidade: uma história da mudança da capital no Piauí (1800-1852).

Vilhena, M. A. G. D. (2006). Vôo de Ícaro: tensões e dramas de um industrial no sertão. Teresina: Marcos Vilhena. 